AWEJ for Translation \& Literary Studies, Volume 5, Number3. August 2021

Pp.113-124

DOI: http://dx.doi.org/10.24093/awejtls/vol5no3.9

\title{
An Ecolinguistic Perspective on Framing of Animals in Quranic Discourse
}

\author{
Ansa Hameed \\ Department of English \\ College of Science and Humanities, Prince Sattam Bin Abdulaziz University \\ Al Kharj, Saudi Arabia \\ Email: a.zahoor@psau.edu.sa
}

\begin{abstract}
Received: 6/22/2021
Accepted: 7/27/2021

Published: $8 / 25 / 2021$
\end{abstract}

Whether animals are of lower rank compared to humans or not is a debatable issue among scholars of various disciplines. However, there is no denying that they play a significant part in sustaining ecological balance on earth. The discourses in this regard play a considerable function in presenting animals in either beneficial or destructive roles. Such studies can contribute to spreading awareness regarding animals' prominence from religious perspectives. The present study aims to examine the religious discourse concerning the ways animals are framed linguistically. For the said purpose, the Quran (the Holy book for followers of Islam) is chosen to analyze the framing technique used to portray animals concerning target words/ phrases. The identified frames are further described with reference to the ecological perspective. The content analysis technique is used to identify target words that are later used to recognize frames. The findings reveal that animals are most importantly presented in four significant frames: as beings, as benefactors, as ornaments, and as celestial signs. These frames further reflect how animals are represented in various roles, from food sources to valuable possession and from war tools to Godly signs. The beneficial story of animals' existence as narrated in the Quran provides a comprehensive overview of their role in bio-network.

Keywords: animals, ecolinguistics, framing, Quranic discourse, target words

Cite as: Hameed, A. (2021). An Ecolinguistic Perspective on Framing of Animals in Quranic Discourse. Arab World English Journal for Translation \& Literary Studies 5 (3) 113-124. DOI: http://dx.doi.org/10.24093/awejtls/vol5no3.9 


\section{Introduction}

The religious books are not just enlisting of some moral codes of conduct mentioned for humans but more often includes a complete description of the world and different other creatures. Quran, as a sacred book for Muslims, in this regard, provides a comprehensive orientation to various mechanisms working together in this enigmatic Universe patterns. Besides humans, animals are also an important part of various religious descriptions and anecdotes. According to Talili (2012), the Islamic tradition has agreed on significant value to animals as living creatures. There are above 200 verses in the Quran that refer to a variety of animals, along with six surahs (a complete chapter) named on some animals. There are almost 31 animals that are specifically mentioned in the Holy book. Thus, it can be deduced that Islam is not about only humans; rather it gives regard to all living beings created for some purposes. This can be closely connected to the agenda of Ecolinguistics.

As a fairly modern approach, Ecolinguistics emerged to question the human agendas with an "anthropocentric" attitude, where humans are regarded as the center of the universe. As a result, they have utilized, exploited, and mismanaged nature and natural resources, including other species like animals. Thus, what Eco-linguistic strives for is an "ecocentric" approach, where the ecology becomes the center of the world. In this defined approach, animals are also considered as an imperative fragment of sustainability goals and are considered as an important schema to talk about. Cook (2015) argues that Ecolinguistics has taken the responsibility to expose the discursive depiction of animals in various human discourses. Stibbe (2012) explains how animals' erasure in essential human discourses is an important point of argument in the platform of Ecolinguistics. He further maintains for evaluating the various "stories" -values that help humans to act, think and talk (Stibbe, 2015) from various sources to understand their ecological implications.

In the light of the above-mentioned notes, the present study is interested in evaluating how the Quranic discourse presents the other creations with a particular focus on animals, in other words, what Stibbe (2015) calls "stories". There have been few studies that have already analyzed the ways animals are presented in the Quran (For example, Khalid, 2010; Tilili, 2012; Foltz, 2014); however, the present study uses a different technique to explore further the texts, as well as the approach i.e., Ecolinguistics. The technique for the said purpose used is framing. It helps to reflect how animals have been framed in the selected divine discourses (ones that are not definitely by humans). According to Nijland, Aarts, and Woerkum (2018) framing of animals is a contested issue as frames are most likely context-sensitive, thus the present study examines it from a new contextual perspective i.e. religion. For the present study, Quranic verses provide the source texts. The various animals mentioned in the Holy book are analyzed with reference to the framing technique. The key research objectives are to:

- To analyze how animals are framed in Quranic text

- To examine the framing strategy used for animals with reference to the Ecolinguistic approach

- To evaluate the selected religious discourse for animal "stories" (Stibbe, 2015)

For this purpose, the research mainly deals with the following research questions: 
- How are animals framed linguistically in the selected verses of the Quranic discourse?

- How animals framing in Quran can be interpreted from an ecological perspective?

- What kind of ecological stories (beneficiary/destructive/ambivalent) are found in Quran with respect to animals?

The research is significant to understand the religious texts as embodiment of Divine philosophy regarding various creations. It helps to shed light on Islamic perspectives regarding nonhuman creations as a significant part of ecology. Moreover, it aims to contribute to the domain of Ecolinguistic research depository in particular and Linguistics in general.

\section{Literature Review}

This section outlines a comprehensive commentary on the relevant terms, concepts, and theoretical propositions. The discussion begins with reference to the term "animal" in the Holy Book, or which is often referred to as nonhuman. In order to understand this concept, it is important to mention that word "Khalq" (which means creations) in various grammatical forms appears several times in the Quran, referring to all creations. This refers to all beings including jinns (a nonhuman creature made of fire in Islamic perspectives), humans, floras, faunas, and the world itself (Khalid, 2010). According to Tlili (2010), animals are referred to as "Dabba", a term that is used in the Quran to refer to all types of living creations including humans and nonhumans; however not the plants as the term Dabba refers to something with the ability to walk, creep or crawl. Contrary to human possessive attitude towards the world, Quran clearly provides the idea that all types of creatures have their roles in the system, as it is mentioned: "And the earth, He has assigned it to all living creatures" (Quran 55:10). Thus, it should be understood that Quran does not and only not talks about humans as supreme creations (which is a more anthropocentric approach). However, there is also no denying fact that Quran addresses only humans to exemplify and elucidate the righteous path. Thus, as having souls along with the reason (something given to humans and not to animals), they are given more roles and responsibilities towards all other creations as well (Tlili, 2010). The verse (Quran 6:167) explains the human role as of "Khalifa" which is in fact a role of trusteeship with moral responsibility (Tlili, 2010). Thus, humans have also responsibilities towards animals; however, it should not be confused with their centrality or prominence over other creatures.

Tlili (2012) explains that as a celestial discourse, Quran is not just about humans but has managed to include all species in the agendas of talk. As discussed above, humans are given the role of a caretaker to other species thus; it can be assumed that animals are also an important part of the world. There are several animals that are directly mentioned in the Quran in various verses. Beheshti (2017) in her studies related to animals mentioned in the Quran focuses on various Islamic philosophies to elucidate connections between animals and humans. She highlights the various roles assigned to animals based on moral perspectives highlighted by various Islamic scholars (Beheshti, 2017). The present research is different in the sense that the main aim is to examine the different frames in which animals are portrayed in the Quranic verses with respect to Ecological concerns. 
Ecolinguistics is a domain that focuses on the use of language for and from ecological perspectives. Bang and Trampe (2014) have defined Ecolinguistics as an umbrella term covering two research traditions: "on the one hand traditional linguistic methods applied on texts and discourse of ecological importance and on the other hand deeper reflections on the theories of language inspired by the holistic paradigm of ecology" (p. 83). Stibbe (2015) considers it as a way to analyze stories of the ways human beings live in this world and the stories of the different sources they believe. The term story is well defined by Okri (1996) as a reservoir of values followed and maintained by the human race. However, these stories become unhealthy when based on some anthropological values. According to Kingsnorth and Hine (2009), the most fatal of the stories is the one where the human race is considered supreme and more valuable than the other creatures. Stibbe (2015) contemplates it important to re-evaluate such stories.

The stories that can be of concern to Ecolinguistics have various sources including the religion that is of the main concern in the present study. The study is interested to evaluate how the Quranic discourse presents the other creations with a particular focus on animals. Ecolinguistics uses a variety of tools to analyze texts, for example, framing, critical discourse analysis, metaphoric analysis, erasure techniques, etc. The present study uses framing as the main tool and is explained further in the impending paragraphs.

The framing technique is based on the concept of frames that can also be referred to as cognitive schemata- the framework of storage as well as interpretation of knowledge used by the brain. Dewulf, et al (2009) define frames as "mindsets or mental filters" (p. 157) that humans use to perceive reality and further use to infer new information based on the already existing frames. Nijland, Aarts and van Woerkum (2018) consider frames as a result of semiotic behavior that helps us to construct charters of understanding. These frames initially help us to make sense of reality (thus creating knowledge) and further to relate any new knowledge with existing ones. However, in the case of new knowledge, new frames can also be constructed. The present study uses the concept of framing as a dynamic activity that helps to make sense of the world as also mentioned by Aarts and van Woerkum (2006). They narrate that "frames are constructed and legitimated in interaction by combining and integrating cognitive building blocks referring to previous experiences, expectations, and objectives concerning the issue at stake (content), the actors involved (relations) and the process that takes place (process)" (para 24).

To be more precise of framing from the Ecolinguistics perspective is considered as a technique of creating stories that people use further to make sense of ecology (Stibbe, 2015). According to Stibbe (2015), we live in connection with the other parts of the world including the other creatures, thus human stories are important to analyze and understand. Midgley (2011) defines stories as equivalent to myths which can be defined as "imaginative patterns, networks of powerful symbols that suggest particular ways of interpreting the world" (p. 1). In other words, stories are the ways of elucidation- or what we use to make sense of the world (thus closely related to framing concept). Stibbe (2015) delineates stories as an important "cognitive structure" (p.6) because they later inspire the ways humans recognize their world. This can be supported with symbolic convergence theory (Bormann, 1985) which explains the connection between language and stories. In other words, people initially use language to construct stories and further these 
stories when become popular narratives are converged to frames. These frames act as a source of inspiration to understand the world around us.

There are many studies available that have been based on the use of framing techniques from ecological concerns. Foust and Murphy (2009) identified framing and reframing strategies in the discourse related to environmental catastrophes. Christmas, Wright, Morris, Watson, and Miskelly (2013) investigated various techniques used to frame biodiversity elements in common public conversational discourse. Nijland, Aarts, and Woerkum (2018) conducted a study in the selected European context to identify and analyze framing techniques used to refer to frame animal farming and meat consumption. Their study reports various frames that are used to talk about animals in relevance to various complex cultural and personal contexts. Lynteris (2019) has focused on the issue of how animals are framed as plague carriers in the various texts and resented as evil creatures. McMurray and Pullen (2020) explain how human superiority is forced over animals in variety of discourses. Schwartz (2020) objects that such discourses are created to objectify animals for exploitation purposes. Such human stories represent a negative character of animals' existence and as per Stibbe (2012) can be considered as dangerous stories as they negate the existence of an important living species.

\section{Research Methods}

The present study uses Stibbe's (2015) framework of framing from an ecolinguistic perspective. According to Stibbe (2015), framing is a technique to impose (within cognition parameters) a story from one area of life to another one. Further, the framing analysis involves examining the use of source frames (knowledge schema) to structure the target domains. In this regard, what is more important is to locate the trigger words that are used to bring a particular frame in action in mind. Thus, it involves the two steps analysis: identification of trigger words to identify various frames (which can be termed as data collection procedure from the content analysis of the selected text) and secondly to arrange frames with the associated trigger words (this is related to the presentation of findings in an appropriate manner). Though the study involves the quantitative approach while focusing on individual words and phrases but at the same time quantification is not the main objective of the research. The discussion involves the interpretation of the frames with reference to the ecological implication. Thus, the overall research paradigm is based on a mixed-method approach. The content analysis technique is used at the data collection stage to identify and examine the trigger words/ phrases. The results are presented and discussed under different headings.

The data to be analyzed is comprised of Quranic verses. As mentioned above, there are 31 animals (including birds and insects) that are mentioned in the Holy Quran with their names. This list includes ant, ape, bee, bird, calf, camel, cattle, cow, crow, dog, donkey, elephant, ewe, fish, fly frog, goat, hoopoe, horse, lice, lion, locust, mosquito, moths, mule, pig, quail, snake, sheep, spider, and wolf (alphabetically listed). Around 140 verses from the Quran are selected (purposive sampling) which have directly mentioned an animal name.

Arab World English Journal for Translation \& Literary Studies 


\section{Findings}

The analysis of the selected texts reveals the following frames used to talk about animals in the Quranic verses.

\section{Frame One: Animals as Beings}

The first source frame is animals talked about as beings- living entities. This frame is built on the habitual deeds of animals as portrayed with a variety of sub-frames like having a habitat, living in a community system, communicating with other beings, and worshipping with a purpose. The target words/phrases for the habitat frame include "the atmosphere of the sky" (Quran 105:3) for the birds, "dwellings" (Quran 27:18) for the insects like ants, "the sea" (Quran 7:163) for the fish, and "among the mountains, houses, and among the trees" (16:68) for bees. The frame of the community system is observable through the use of the following target words/ phrases: "birds in flocks" (Quran 105:3), "valley of the ants" (Quran 27:18), "communities like you [humans]" (Quran 6:38). One of the interesting features specified to animals in the Quran is a referral to a communication system. The target words/ phrases for this frame include: "an ant said (to other ants)" (Quran 27:18), "the language of the birds" (Quran 27:16), "repeating (praises to God)" (Quran 38:19), Solomon has the ability to talk to animals as narrated "he took attendance of the birds" (Quran 27:20); however, this communication system is different from humans as mentioned, "you do not understand their exalting" (Quran 17:44). The interesting fact here is that one of the prophets 'Sulaiman' was taught the language of the birds and insects and few verses refer (quoted above) to this interesting situation. The first instance is where Suleiman overhears the ants and secondly when Hoopoe informs him about the kingdom of princess Sheba. This sort of communication is impossible if animals are considered to be without language. Ali and Abdullah (2019) have cited various examples from Quran to report that animals' language is as valid as humans' language and cannot be restricted to be defined as a mere set of informative signals (Yule, 2017). Another important feature of humans' lives is to look for some spiritual support and is evident through various religions. This feature is also evident among animals as living communities. Various target words/ phrases can be traced which highlight the fact that animals are also worshippers: "has known his means of prayers and exalting" (Quran 24:41), "repeating (praises to God)" (Quran 38:19), "to exalt along with (...) birds" (Quran 21:79), "everything (living and non-living) prostates to God" (Quran 22:18).

\section{Frame Two: Animals as Benefactors}

This second frame is important to identify how the ecological system has been kept in balance by creating a chain (where animals have an important role to provide humans with some of their necessities). This frame as benefactors or providers mainly is constructed on three subframes: animals as a food source, as an assistance source, and as a war source. The first important frame is of animals as food providers which can be identified through various target words/ phrases, like: "Eat (quail)" (Quran 2:57), "food for Moses nation (birds)" (Quran 20:80), "prohibited every animals of uncloven hoof (rest are allowed)" (Quran 6:146), "to slaughter a cow" (Quran 2:67), "as beast of burden and food" (Quran 16:5), "lawful for you (to eat)" (Quran 5:1), "roasted calf (for eating)" (Quran 11:69), "leave her to eat (others can be eaten except her)" (Quran, 7:73), and "fish came to them (as food)" (Quran 7:163), "lawful for you are the animals of grazing livestock" (Quran 5:1), "drink from what is in their bellies (for example, milk)" (Quran 16:66), "Eat and pasture your livestock" (Quran 20:54), "[sacrificial] animals. So eat of them" (Quran 
22:28), "drink from that which is in their bellies, (.....) you eat." (Quran 23:21), "some of them you eat" (Quran 40:79).

The second sub-frame in this category is of assistance role which is based on the ways animals provide help to humans, for example as means of transportation, as a beast of burden, or as a work tool. The target words/ phrases for this frame include: "as a beast of burden" (Quran 16:5), "horses, mules, and donkeys for you to ride" (Quran 16:8), "a donkey who carries" (Quran 62:5), "other uses" (Quran 20:18), "a camel's load" (Quran 12:72), "livestock are carriers [of burdens]" (Quran 6:142), "livestock (.....) [numerous] benefits" (Quran 16:5), "animals (....) Day of travel" (Quran 16:80), "numerous benefits" (Quran 23:21), "animals upon which you ride" (Quran 40:79), and "animals those which you mount" (Quran 43:12). This frame highlights how useful animals are in various roles.

The next category is animals presented as war assistance or tools. The following target words/ phrases help to identify this frame: "steeds of war" (Quran 8:60), "assault them with your horses" (Quran 17:64), "gathered for Solomon were his soldiers of the jinn and men and birds" (Quran 27:17), "companions of elephants (a war group)" (Quran 105:1), and " [in an expedition] any horses or camels" (Quran 59:6).

\section{Frame Three: Animals as Ornaments}

Another interesting frame is of ornaments in which animals are portrayed as a source of pride, valuable possession, and enjoyment. The following target words/ phrases help to identify this frame: "(animals) the enjoyment of the worldly life" (Quran 3:14) "fine branded horses, and cattle" (Quran 3:14), "poised racehorses" (Quran 38:31), "(as) adornment" (Quran 16:8), "their wool, fur, and hair is furnishing and enjoyment for a time" (Quran 16:80).

\section{Frame Four: Animals as Celestial Instruments}

This is one of the important frames found abundantly in the Quran where animals were presented as a different creation from humans but at the same time framed as signs, miracles, and examples to teach lessons to humans. This frame is important as it clarifies that animals are not just created for animal use but have their own purposes. Quran uses animals to exemplify and elucidate the various beliefs and commands that humans need to follow to fulfill their duties on earth. The reason presented is very clear that they are being given the reason and wisdom by the Almighty and they need to act accordingly. It is the reason that makes them totally different from the human species and at the same time responsible for their deeds.

The first sub-frame in this category is of the animals as signs. This can be further divided into three categories: signs of smart creation, signs of punishment, and signs of dreams. The target words/ phrases in the first sub-frame "sign of clever creation" include: "not look at the camelshow are they created" (Quran 88:17), livestock are various colors" (Quran 35:28), "fine branded horses" (Quran 3:14), "created animals from water (...) some creeping on their bellies, some walk on two legs, some on four" (Quran 24:45). The second sub-frame is animals as a sign of punishment and is presented through following target words/ phrases: "snatched by the birds" (Quran 22:31), "birds (....) Eat his head" (Quran 12:41), "made of them apes and pigs 
(disrespectful humans converted to animals as punishment)" (Quran 5:60), "sent upon them, (...) the locusts, and lice and frogs" (Quran 7:133), "fish swallowed him, while he was blameworthy" (Quran 37:142). Animals are also framed as signs in a dream in few instances like "[in a dream] seven fat cows" (Quran 12:43) and "in a dream, birds eating from my head" (Quran 12:36).

Another important sub-frame in this category is of animals as miracles, presented to humans either as a symbol of power or symbol of trial. In this regard, Quran presents various incidents. This frame is identified on the basis of the following target words/ phrases: "she-camel of God ... as a sign" (Quran 7:73), "she-camel as a visible sign" (Quran 17:59), "she-camel as a trial for them" (Quran 54:27), "look at the bones [of this donkey] (.....) raise them and then We cover them with flesh" (Quran 2:259), "Moses threw his staff and it was a serpent" (Quran 7:107), "designed from a clay-like form of a bird (...) became a bird" (Quran 5:110), "four birds ....(after slaughtering) put on each hill (came back alive)" (Quran 2:260), "companion of fish (Younus engulfed by fish and then came back alive)" (Quran 68:148). These frames clearly represent the idea of how animals were used to depict miraculous powers to some of the prophets and at the same time as given trials to some nonbelievers.

The third sub-frame is of animals as examples that are used to teach lessons. The target words/ phrases for this frame include: "apes and pigs, slaves of aghut (desires)" (Quran 5:60), "weakest of the homes is the home of spider" (Quran 29:41), "who understand but still deny... like a donkey who carries volumes" (Quran 62:5), "(crow) buried the body" (to teach what to do with dead people) (Quran 5:31), "follow their desire are like a dog" (Quran 7:176) "those who took the calf, will obtain anger" (as worshipping animals is not allowed) (Quran 7:152), "horses and cattle's (...) enjoyment of the worldly life" (Quran 3:14), "disbelievers (...) like animals" (as animals are not given reason and wisdom) (Quran 47:12), "emerged from graves as locusts spreading" (Quran 54:7).

\section{Discussion}

Framing is one of the useful linguistic techniques to identify how various concepts are portrayed in a text. The following study identified some major frames like animals as beings, animals as benefactors, animals as ornaments, and animals as celestial instruments based on target word identification. This section incorporates an ecological perspective to the findings. The first major frame identified is animals as beings or living entities. Various sub-frames like habitat, community system, language system, and the worshipping system help us to verify how animals are created with a purpose along with other living beings. The second frame i.e. animals as benefactors are more inclined towards the idea that animals have a specific role in the ecological system as they tend to provide various type of services to humans (as food supply, transportation means, war source). The third frame highlights animals as adornments and the final frame identifies their usage as signs and miracles used by God. All of these frames highlight various aspects of animals' existence and prominence.

Animals have a proper living system though different from humans, as per the target words recognized in the various frames. Quran does not comment on the inferior status of the animals but a different one. For example, the idea that humans who do not use their wisdom and 
understanding to perform their worldly duties are compared to animals because the animals are made as creatures without wisdom (or the power of cognition). Thus, it shows how animals are made different from humans and have their own assigned roles and responsibilities. This idea goes with an ecocentric approach where all beings have their own value and contribution. According to Marcot and Heyden (2001), the idea of a sustainable system purely belongs to the idea that all organisms (including humans and nonhumans) play their parts which are different but substantial in their space. For example, animals portrayed as benefactors (as food sources and beasts of burden) have their role to maintain ecology. Elton (n.d) comments that without animals in the roles of food providers, the balance of the food chain (which is an important factor in ecology) is unimaginable.

The idea that is often proposed that humans have been given a supreme role in the Islamic traditions or what is referred to as anthropocentrism (Foltz, 2014) is rather negated by the role assigned to them as caretakers ("khalifa" Quran 6:167). This role makes their living more accountable as they have a responsibility towards all living creations on the planet. However, this understanding is often presented within a biased frame of anthropocentrism (Tilili, 2012). For example, various roles assigned to animals in the Quranic texts like as livestock, as food source, as ones lacking wisdom, as ones created to serve humans are quoted to pinpoint an understanding of where humans occupy a supreme role. Tilili (2012) rejects this idea on the grounds that as the Quran is a book directly addressed to the humans with a purpose of teaching and thus mainly focused on human-based issues; animals are not given a direct role as it is not given to other species created by God including angels and jinns. "However, this interest is not necessarily an indication either of a privileged status or of a particular divine preference for humans" (Tlili, 2012, n.p). This could be better understood through the analogy that a book written for medical students may add some contents of engineering (medical engineering, biotech, etc.) but is more focused on the medical field. It does not mean at all that the engineering field is inferior to a medical one. Once again, the simple point is that the book addresses humans and offers them a complicated role with the burden of duties towards other creatures specifically flora and fauna.

It is also understandable that the Quranic text uses animals' examples to teach lessons to humans. They have been reported as dream symbols, as God's test, as Deity's signs, and as vivid examples, as per the findings of the fourth frame reveals. This gives an idea that animals are not just created as food or beasts of burden to serve humans rather they have their own strengths, weaknesses, and living system which can be symbolized. From a fly to a locust and a wolf to a horse, many types of animals are characterized by their individual identities (whether good or bad, as humans also fall in both categories). This goes in contrary to what Derrida (2008) states "Cartesianism belongs, beneath its mechanicist indifference, to the Judeo-Christiano Islamic tradition of a war against the animal" (p. 101). Tlili (2018) also rejects this idea as she says such ideologies are based on an inaccurate interpretation of the Quranic and Islamic traditions. Singer (2009) argues that there is no ethical ground to debate about the inferior status of animals as they are different species and appear different, like humans of different races appear to be different.

With an understanding that how animals are framed linguistically in the selected religious discourse, it is easy to comment that Quranic text does not underestimate the animals' significance 
and role in sustainable eco-mechanism. Stibbe (2015) calls such discourses beneficial stories as they help to raise awareness about the importance of various species in sustainable living. These findings are contrary to what is depicted in discourses created by humans. For example, Lynteris (2019) and McMurray and Pullen (2020) report the negative portrayal of animals in the various discourses, as plague carriers (destructive stories) or as resources (destructive stories). Such stories insist on the negative side of animals where they seem to transport destructive elements.

\section{Conclusion}

The present study aimed to study the ways animals were linguistically framed in the Quranic texta Divine discourse from an ecological perspective. For the said purpose, Stibbe's (2012) charter of framing and ecology was used. The target words/ phrases from the Quran were identified using the content analysis method. These target words were used to identify the various main and subframes in which animals were portrayed in the various Quranic verses. In this regard, only highly visible frames were focused and further interpreted from an ecological standpoint. The findings revealed various main and subframes representing animals as living creatures, as ornamental possessions, as potential benefactors, and as celestial signs. All of these frames can be interpreted to consider animals as capable beings created for various purposes to maintain and sustain the ecological balance of the world. The animals as part of the ecocentric world have their worth and character as per the several frames found in the Quranic text. It can be concluded that Quran (being a book addressed to humans) does not undervalue the importance of other creatures rather present them in various frames in which they are valuable for sustainable ecology.

\section{Acknowledgment:}

The researcher is obliged to Deanship of Scientific Research at Prince Sattam bin Abdulaziz University, Al Kharj, Saudi Arabia for the motivation and support.

\section{About the Author}

Dr Ansa Hameed is currently working as an Assistant Professor at Prince Sattam Bin Abdulaziz University, Saudi Arabia. She has received her Ph.D. degree from NUML Islamabad in 2013. She has interests in contemporary domains of Linguistics including Ecolinguistics, Corpus Linguistics, Discourse Analysis and ELT. ORCID ID: https://orcid.org/0000-0003-3477-156X

\section{References}

Aarts, N.M.C. \& Van Woerkum, C. (2006). Frame construction in interaction. In MultiOrganisational Partnerships, Alliances and Networks. Engagement, Proceedings of the 12th MOPAN International Conference, Wales, UK, 22-24 June 2005; Short Run Press: Exeter, UK, 2006.

Ali, W. I. \& Abdullah, I. A. (2019). Animal language in the Quran: The application of Charles Hockett design features. International Journal of Psychosocial Rehabilitation, 23(2), 764-771. DOI: 10.37200/IJPR/V23I2/PR190329

Bang, J. C. \& Trampe, W. (2014). Aspects of an ecological theory of language. Language Sciences, 41 (part A). 83-92. https://doi.org/10.1016/j.langsci.2013.08.009

Beheshti, S. (2017). Animals in the Quran: The Epistemological Significance of Sacrifice, Personhood, Vegetarianism, Mercy and Dominion through the Lens of Islamic Moral 
Philosophies. Retrieved from

https://www.academia.edu/35432450/Animals_in_the_Quran_The_Epistemological_Sign ificance_of_Sacrifice_Personhood_Vegetarianism_Mercy_and_Dominion_through_the_ Lens_of_Islamic_Moral_Philosophies?email_work_card=view-paper

Bormann, E.G. (1985). Symbolic convergence theory: A communication formulation. $J$. Commun., 35, 128-138.

Christmas, S., Wright, L., Morris, L., Watson, A. \& Miskelly, C. (2013). Engaging people in biodiversity issues: Final report of the biodiversity segmentation scoping study. London: Simon Christmas.

Cook, G. (2015). 'A pig is a person' or 'You can love a fox and hunt it': Innovation and tradition in the discursive representation of animals. Discourse \& Society 26(5), 587-607.

Cook, G. \& Sealey, A. (2017). The Discursive representation of Animals. In A. Fill \& H. Penz (eds.), The Routledge Handbook of Ecolinguistics. New York: Routledge.

Derrida, J. (2008). The animal that therefore I am. New York: Fordham University Press.

Dewulf, A., Gray, B., Putnam, L., Lewicki, R., Aarts, N., Bouwen, R., \& van Woerkum, C. (2009). Disentangling approaches to framing in conflict and negotiation research: A meta-paradigmatic perspective. Human Relations, 62 (2), 155-193. https://doi.org/10.1177/0018726708100356

Elton, C.C. (n.d). Animal Ecology. Nature, 119, 193-193.

Foltz, R. (2014). Animals in Islamic tradition and Muslim cultures. Simon and Schuster.

Foust, C. \& O'Shannon Murphy, W. (2009). Revealing and reframing apocalyptic tragedy in global warming discourse. Environmental Communication: A Journal of Nature and Culture, 3, 2, 151-167.

Kingnorth, P. \& Hine, D. (2009). The dark mountain project manifesto (online). Available at http://dark-mountain.net/about/manifesto/

Khalid, F. (2010). Islam and the environment: Ethics and practice an assessment. Religion Compass, 4, 11. Blackwell Publishing. DOI: 10.1111/j.1749-8171.2010.00249.x

Lynteris, C. (2019). Tarbagan's winter lair: Framing drivers of plague persistence in Inner Asia. In C. Lynteris, (Ed.) Framing Animals as Epidemic Villians (n.p). Palgrave McMillan.

Marcot, B. G. \& Heyden, M. V. (2001). Key ecological functions of wildlife species. In In D. H. Johnson, \& T. A. O’Neil (eds.), Wildlife-Habitat Relationships. USA: Oregon State University Press.

McMurray, R., \& Pullen, A. (eds.) (2020). Gender, Embodiment and Fluidity in Organization and Management (Routledge Focus on Women Writers in Organization Studies). New York: Routledge.

Midgley, M. (2011). The Myths We Live by. New York: Routledge.

Nijland, H. J., Aarts, N. \& Woerkum, C. M. J. V. (2018). Exploring the framing of the animal farming and meat consumption: On the diversity of the topics used and qualitative patterns in selected demographic contexts. Animals, 8(2), $17 . \quad$ DOI: https://doi.org/10.3390/ani8020017

Okri, B. (1996). Birds of heaven. London: Phoenix.

Singer, P. (2009). Animal Liberation (4 ${ }^{\text {th }}$ ed.). USA: Harper Collins.

Schwartz, B. (2020). The Animal Welfare Battle: The Production of Affected Ignorance in the Swedish Meat Industry Debate. Culture and Organization 26(1): 75-95 
AWEJ for Translation \& Literary Studies Volume, 5 Number 3. August 2021

Stibbe, A. (2012). Animals Erased: Discourse, Ecology, and Reconnection with the Natural World. Middletown: Wesleyan University Press.

Stibbe, A. (2015). Ecolinguistics: Language, ecology and the stories we live by. Routledge. DOI: $10.4324 / 9780367855512$

Tlili, S. (2010). The Meaning of the Qur'anic Word 'dabba': Animals' or 'Nonhuman Animals? Journal of Quran Studies, 12. Edinburgh University Press on behalf of the Centre for Islamic Studies as SOAS.

Tlili, S. (2012). Animals in Quran. Cambridge University Press.

Tlili, s. (2018). Animal ethics in Islam: A review article. Religions, 9(9), 269. MDPI AG. Retrieved from http://dx.doi.org/10.3390/re19090269.

Yule, G. (2017). The Study of Language (6 ${ }^{\text {th }}$ ed.). Cambridge University Press. 